\title{
Ecology of bottom biocoenoses in the Possjet Bay (the Sea of Japan) and the peculiarities of their distribution in connection with physical and chemical conditions of the habitat
}

\author{
Alexandr N. Golikov and Orest A. Scarlato \\ Zoological Institute of the Academy of Sciences, Leningrad, USSR
}

\begin{abstract}
KURZFASSUNG: Okologie der Bodenbiozönosen in der Posjet-Bucht (Japanisches Meer) und die Besonderheiten ihrer Verbreitung in Verbindung mit physikalischen und chemischen Bedingungen des Habitats. Verbreitung und Zusammensetzung der Fauna und Flora der reichbesiedelten, oberen marinen Wasserzonen sind nur ungenügend bekannt, weil große Forschungsschiffe mit geeigneten Einrichtungen zum Sammeln und zur Datenverarbeitung in küstennahen Gewässern wegen der geringen Wassertiefe nicht arbeiten können. Die Anwendung autonomer Tauchausrüstungen hat es uns ermöglicht, direkte Beobachtungen an litoralen Biozönosen durchzuführen. Je nach Größe und Besiedlungsdichte der angetroffenen Organismen haben wir Areale von $100 \mathrm{~m}^{2}$ bis zu $1 / 100 \mathrm{~m}^{2}$ untersucht. Qualität und Quantität der Bodenorganismen hängen nicht nur von der Beschaffenheit des Untergrundes $a b$, sondern auch von physiko-chemischen Umweltfaktoren sowie vom Nahrungsangebot und dem „biozönotischen Hintergrund" (biotischen Faktoren). In Astuarien und Lagunen beeinflußt der Salzgehalt in starkem Maße die artliche Zusammensetzung der Biozönose, wobei der Salzgehaltseinfluß in der Endofauna geringer ist als im Phytal und bei der Epifauna - ein Umstand, der vermutlich mit dem relativ höheren Salzgehalt innerhalb des Bodens zusammenhängt. Verbreitung, Komposition und biographische Struktur der Biozönosen werden primär von der Wassertemperatur (absolute Intensität und Fluktuationsmuster) beeinflußt. In halb abgeschlossenen Meeresbuchten und flachen Litoralgebieten neigen die Biozönosen immer mehr zu kleinflächigen Verbreitungsmustern. Diese Veränderungen hängen möglicherweise zusammen mit (a) intensiveren Fluktuationen der physiko-chemischen Verhältnsse, (b) deren zunehmende Variabilität und (c) beschleunigter Sukzession. Die Verbreitung der Organismen ist sehr eng gebunden an die Positionen bestimmter Wassermassen. Bei der Durchführung biogeographischer Studien sollten - zusätzlich zu Vergleichen ähnlicher Vertikalzonen - bionomisch ähnliche Gebiete analysiert werden. Die Einwanderung von Warmwasserorganismen von einer Warmwasserzone in die andere erfolgt vermutlich während Perioden, in denen die intermediären Gebiete starken Oberflächenerwärmungen ausgesetzt sind.
\end{abstract}

\section{INTRODUCTION}

The distribution of life and the composition of the fauna and flora in the richest upper marine zones is insufficiently known since large research vessels with high capacities of collection and quantitative calculation cannot work in coastal waters because 
of their small depths and bottom relief. As for sweeping, dredging and bottomsampling from boats and small vessels, these means are not very efficient in algae and marine grass beds prevailing in the upper sublittoral and on hard gravel-pebbly, rocky and stony grounds (Drach 1958, Scarlato, Golikov \& Gruzov 1964, GoliKOV \& SCARLato 1965).

\section{METHODS}

The use of autonomous diving technique has obviated the majority of difficulties in the study of the life of coastal waters and has enabled us to carry out direct observations on the biocoenoses in the upper marine zones and to undertake accurate quantitative studies of bottom animals and plants.

In the summer of 1962 and in different seasons of 1965, hydrobiologists of the Zoological Institute of the Academy of Sciences of the USSR studied bottom biocoenoses of the Possjet Bay by means of the diving technique. The population of each biotope was studied quantitatively in areas ranging from $100 \mathrm{~m}^{2}$ (FOSTER 1959) to $1 / 10$ and $1 / 100 \mathrm{~m}^{2}$ depending on the sizes of the organisms and their densities. For taking quantitative samples from $1 \mathrm{~m}^{2}$ and smaller areas special devices were used, such as "diving quantitative bells" for calculation of data regarding submarine plants and the animals associated with them, and "diving bottom samplers" for calculation of data concerning epifauna and infauna on different grounds (Scarlato, Golikov \& Gruzov 1964, Golikov \& Scarlato 1965). Simultaneously with biological works, a hydrophysical and hydrochemical survey was undertaken. Depths up to $25 \mathrm{~m}$ were studied.

\section{RESULTS}

A great variety of grounds, relatively high summer water temperatures (reaching $22^{\circ}$ to $24^{\circ} \mathrm{C}$ in protected areas), a rather high salinity (very seldom below 28 to $30 \%$ ), and the location of the Possjet Bay not far from the border between two biogeographical superregions (boreal-arctic and tropical-subtropical) caused a considerable variety both in the fauna and flora. In the Possjet Bay about 540 species of animals and 88 species of plants were discovered among bottom living organisms. Gastropods and bivalves, polychaetes, amphipods and algae dominate here by the number of their species. In biocoenoses of the upper sublittoral, bivalves, echinoderms, polychaetes, algae and marine grass dominate in terms of their biomass. Between tide marks gastropods and amphipods, possessing various adaptations to habitation in variable conditions, prevail.

In the Possjet Bay biocoenoses are most diverse and rich on hard stony and rocky grounds. The greatest number of species and maximal biomasses were found in the algal belt, in the upper sublittoral and in the colonies of aggregatively distributed mussels (Crenomytilus grayanus). On soft, not so richly populated grounds the greatest number of species and the greatest biomass were found also in the belt of marine 
grasses and among algae. These results show that qualitative variety and quantitative abundance of bottom organisms depend not only on the nature of grounds, other physical and chemical environmental conditions or the quantity of food matter available in the free water and on the ground, but also on the biocoenotic background created by a number of species aggregatively distributed in the biotope. These biological-background-forming species create additional ecological niches for the existence and development of many species which cannot live in the biotope in the absence of these forms. This fact must be taken into consideration in the evalution of biocoenoses and distribution of energetic levels within them. Grounds and biocoenotic background determine the composition, structure and distribution of biocoenoses only in areas with similar physical and chemical conditions; they do not play a leading role if depth and bionomic nature of the habitat (especially temperature, salinity and the degree of wave beating) change.

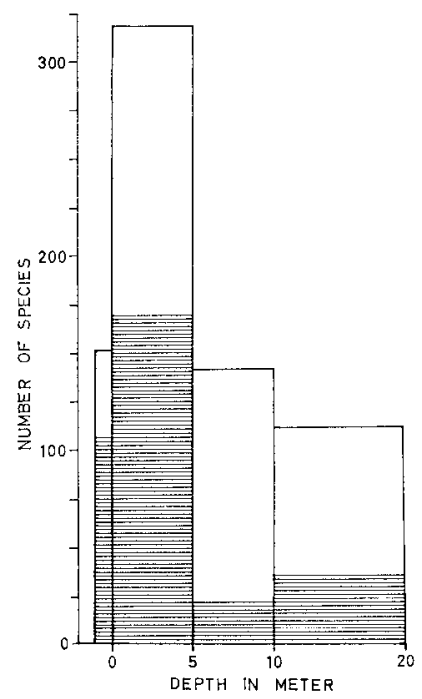

Fig. 1: Dependence of the number of animal and plant species on the depth of their habitat in the Possjet Bay. The shaded part of the diagram corresponds to the number of species for each depth range

In the estuary and lagoon areas of the regions investigated salinity changes affect the composition of biocoenoses to a great extent (criterion: comparison with analogous biocoenoses on identical grounds in non-diluted areas). In brackish waters salinity acts as a limiting factor restricting the distribution of fresh-water and brackish-water species on the one hand and of marine species on the other by a 5 to $9 \% \mathrm{~S}$ barrier. In biocoenoses of diluted areas brackish-water species usually become the leading forms, such as Ovassiminea possietica, Assiminea lutea, Fluviocingula nipponica, Anisogammarus tiushovi, Anisogammarus kygi, Corbicula japonica. The degree of the influence of reduced salinity on the composition of biocoenoses decreases from phytal and epifauna to infauna - a fact which may be associated with the higher salinity of endopsammic waters. 
The most efficient influence upon the distribution, composition and biogeographical structure of biocoenoses is exerted by the water temperature, the absolute values and fluctuations of which being different at various depths as well as in protected and open areas. The study of seasonal fluctuations in bottom biocoenoses of shallow waters of the Sea of Japan has shown that many warm-water species are capable of withstanding winter water cooling and even freezing (enclosure in solid ice). The distribution of organisms depends first of all on hydrological summer temperatures limiting reproductive rates and survival of species; a fact which is in good agreement with Hutchin's rule (1947).

Distribution and species composition of biocoenoses exhibit a tendency toward reduction of the quantitative variety of fauna and flora with the reduction of temperature and the degree of its fluctuation with increasing depths (Fig. 1).

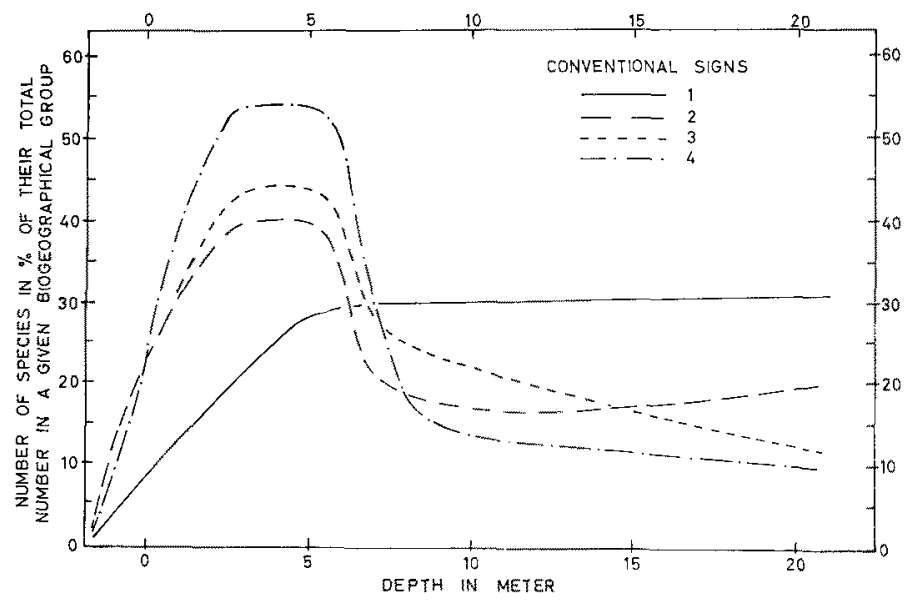

Fig. 2: Distribution of bottom organisms of different biogeographical nature as a function of habitat depth in Possjet Bay: 1: boreal-arctic species, 2: widely distributed boreal species, 3: low-boreal species, 4 : subtropical and subtropical-boreal species

In all cases maximal numbers of species and individuals as well as the greatest biomasses were found at depths ranging from 0 to $5 \mathrm{~m}$. At these depths specific species are rather abundant. Biogeographical genesis of species is known to reflect their relation to the thermic regime.

A biogeographical analysis of biocoenoses at various depths shows a sharp reduction in the number of warm-water subtropical and low boreal species below the $5 \mathrm{~m}$ isobath, while the number of relatively cold-water, boreal-arctic - and to a lesser extent widely distributed boreal - species increases (Fig. 2). Variations in the quantitative, qualitative and biogeographical composition of biocoenoses at $5 \mathrm{~m}$ depth seem to indicate that just here runs the lower border of a special marine vertical zone ( 0 to $5 \mathrm{~m}$ ).

Hydrologically, this zone is characterized during the summer by relatively high temperatures changing little from surface to bottom and depending to a considerable 
extent on the time of day. This zone is defined by the location of the upper layer of the surface aquatic mass of the Japan Sea.

This fact, which was also confirmed by the study of regularities of the distribution of coastal bottom biocoenoses in the Okhotsk Sea (Golmov 1966), shows that in

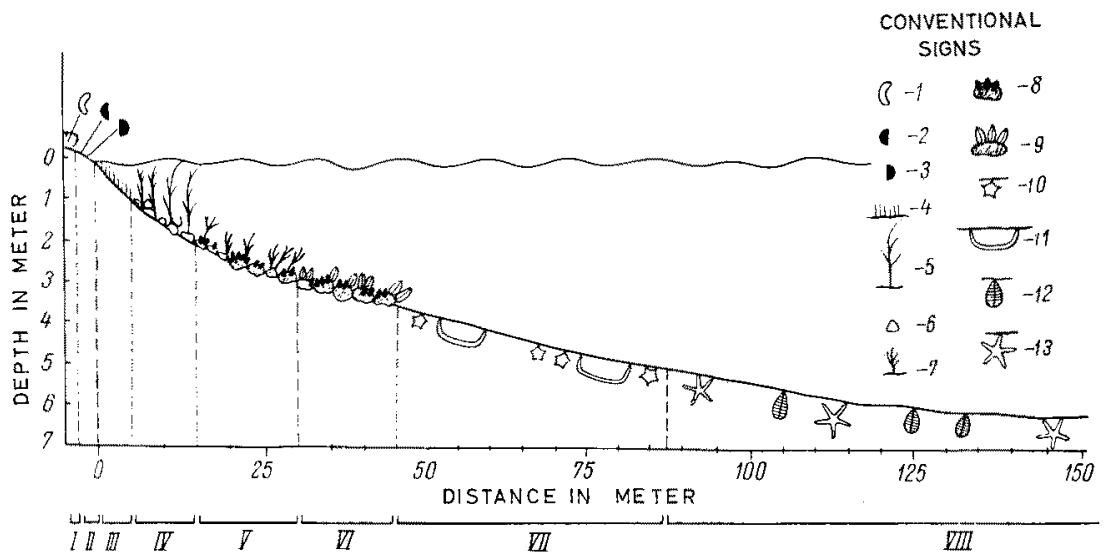

Fig. 3: Scheme of yertical distribution of bottom biocoenoses in half-closed coves of Possjet Bay. I: Biocoenosis of Thalorchestia pachypus (1) + Dermaptera (supra-littoral and upper horizon of the littoral, Zostera marina washed ashore on pebble). II: Biocoenosis of Gnorimosphaeroma noblei (2) + Anisogammarus posseticus (3) (middle and low horizons of the littoral, pebble). III: Biocoenosis of Zostera marina (4) + Musculus senhousia (sublittoral, 0-1 m depth, muddy sand). IV: Biocoenosis of Sargassum kjellmanianum (5) + Tegula rustica (6) (1-2 m depth, stones and sandy gravel). V: Biocoenosis of Sargassum pallidum (7) + Arca boucardi (8) (2-3 m depth, large stones with pebble, gravel and sand). VI: Biocoenosis of Crenomytilus grayanus (9) + Arca boucardi (8) (3-3.5 $\mathrm{m}$ depth, stones on slightly muddy pebble). VII: Biocoenosis of Patiria pectinifera (10) + Chaetopterus variopedatus (11) (3.5$5 \mathrm{~m}$ depth, muddy sand with gravel and shells). VIII: Biocoenosis of Anadara brougbtoni (12) + Luidia quinaria bispinosa (13) (5-6 m depth and more, mud). Sea level here and in Figure 4 corresponds to winter zero of the depth

the system of vertical marine zone there is a very close connection between the distribution of organisms and the location of layers of definite aquatic masses.

Bionomically different areas also differ considerably in the character of the distribution of biocoenoses, their composition and biogeographical structure even on similar grounds and depths. In half-closed areas of the bay the patchiness of biocoenoses increases; it decreases, however, everywhere with depth; biocoenoses rise to smaller depths and the territories occupied by them get smaller in comparison to the distribution of similar biocoenoses of the open coast (Figs. 3, 4). These phenomena may be associated with (1) considerably higher more pronounced fluctuations of physical and chemical conditions, (2) their greater variety and (3) increased frequency of succession in upper marine zones and in half-closed areas as compared with the situation at greater depths and in open areas.

Furthermore, in half-closed water bodies a progressive development of biocoenoses of muddy grounds takes place, occupying ever greater territories and pressing back biocoenoses of other grounds into the very coastal strip. Biocoenoses in half- 
closed water bodies and in shallow waters are less resistant than those off the open coast and at greater depths, and their seasonal and annual successions are more pronounced. Biocoenoses of half-closed, well warmed (summer) lagoons and coves of the Possjet Bay contain a considerable number of subtropical (by origin) species with high biomass (Fig. 5a). The majority of these species do not, or only rarely, occur off

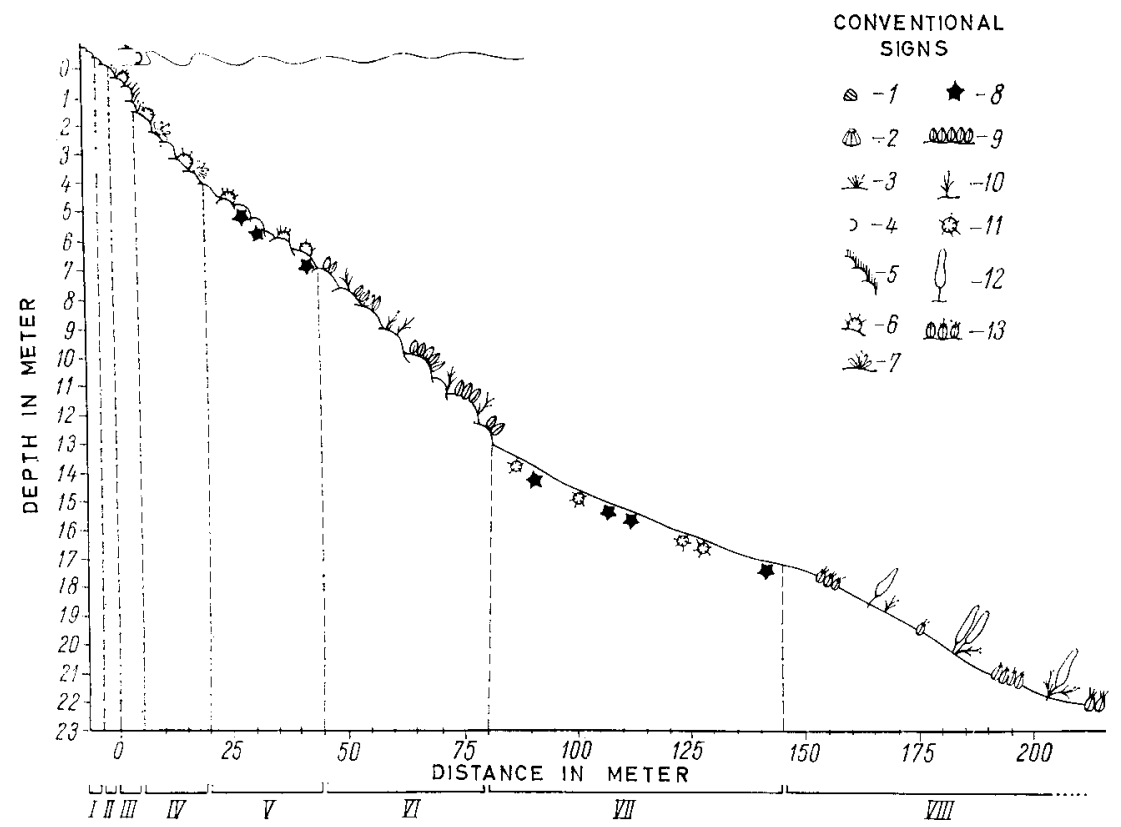

Fig. 4: Scheme of the vertical distribution of the bottom biocoenoses off the open rocky coasts of the Possjet Bay. I: Biocoenosis of Littorina brevicula (1) + Chthamalus dalli (2) (supralittoral and upper horizon of littoral, rocks and stones). II: Biocoenosis of Gratelupia divaricata, Sphaerotrichia dissessa, Laurencia papillosa (3) + Caprella kristibrachium (4) (middle and lower horizon of littoral, rocks). III: Biocoenosis of Phyllospadix iwatensis (5) + Strongylocentrotus nudus (6) (sublittoral, 0-1.5 m depth, rock, stones). IV: Biocoenosis of Scytosiphon lomentaria, Punctaria latifolia, Coccophora langsdorfii (7) + Strongylocentrotus nudus (6) (1.5-4 m depth, rock with stones and gravel in cracks). V: Biocoenosis of Patiria pectinifera (8) + Strongylocentrotus nudus (6) (4-7 m depth, rock). VI: Biocoenosis of Crenomytilus grayanus (9) + Desmarestia viridis (10) (7-13 m depth, rodk with stones and pebble). VII: Biocoenosis of Patiria pectinifera (8) + Echinocardium cordatum (11) (13-17 m depth, muddy sand). VIII: Biocoenosis of Laminaria cichorioides (12), Desmarestia viridis (10) + Modiolus difficillis (13) (17-21 $\mathrm{m}$ depth, sandy mud with shells)

the open coasts. The leading role of subtropical species in nearly all biocoenoses of half-closed water bodies enables us to consider them to be very close to subtropical ones. Biocoenoses of open areas are characterized by the abundance of low-boreal and widely distributed boreal species, the number and biomass of which dominate. That is why these open areas must be regarded as belonging to the low boreal province of the Pacific boreal region (Fig. 5b).

Considerable differences in the biogeographical composition of biocoenoses be- 
tween well-warmed, protected and relatively cool open areas were found in other regions of the Sea of Japan and in the Okhotsk Sea (Golikov 1966).

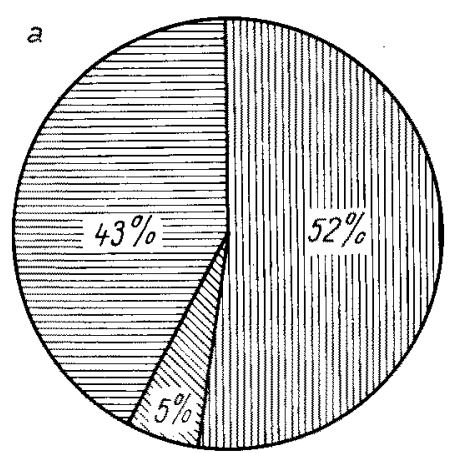

HALF.CLOSED LAGUNS AND COVES

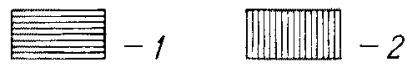

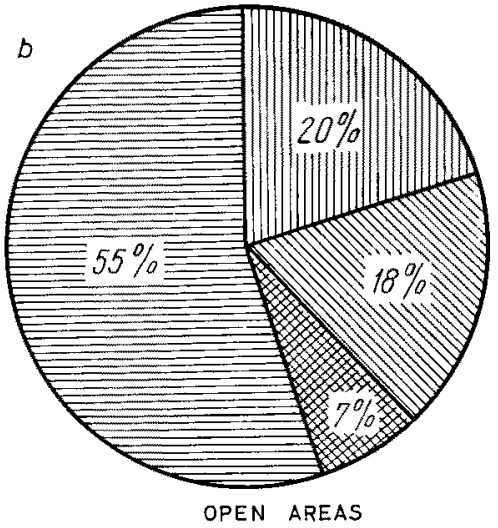

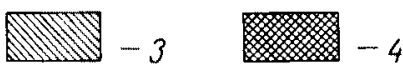

Fig. 5: Biogeographical composition of bottom biocoenoses in various areas of the Possjet Bay which differ in regard to their bionomical nature. (1) low-boreal species, (2) subtropicalboreal species, (3) widely distributed boreal species, (4) boreal-arctic species

\section{CONCLUSIONS}

When carrying out work on biogeographical zonations, it is necessary to compare not only similar vertical zones, as is usually done, but also bionomically similar areas.

The presence of the cold Primorsky current in the western part of the Sea of Japan and the patchiness of species, subtropical in their origin, along the western coasts of the Sea of Japan and Okhotsk Sea leads us to assume that the leading factor in regard to the distribution of organisms is the nature of the thermic regime of coastal waters rather than the system of currents. This thermal regime is defined to a considerable extent by the heat exchange between the sea and atmosphere.

The penetration of warm-water organisms from one protected well-warmed area into another may proceed successfully in the periods when the climate is getting warmer and surface waters in intermediate open areas become sufficiently heated.

\section{SUMMARY}

1. By employing autonomous diving techniques, direct observations on the biocoenoses of the upper marine zones were carried out. The population of each biotope was studied quantitatively in areas from $100 \mathrm{~m}^{2}$ to $1 / 10$ or $1 / 100 \mathrm{~m}^{2}$ depending on size and density of the organisms studied.

2. The quality and quantity of bottom organisms depend not only on the nature of 
the ground, other physico-chemical environmental factors or the quantity of food available, but also on the "biocoenotic background", i. e. conditions created by aggregations of certain species whose presence create additional, new niches.

3. In estuaries and lagoons, salinity greatly affects biocoenosis composition. The effect of salinity changes increases from phytal and epifauna to infauna elements, a fact which may be associated with the relatively higher salinity inside the bottom substratum.

4. The most highly effective force in determining distribution, composition and biogeographical structure of biocoenoses is the water temperature (absolute values as well as fluctuations).

5. In half-closed areas of bays the patchiness of biocoenoses tends to increase and the territories occupied become smaller. These changes may be associated with (a) higher fluctuations of physico-chemical conditions, (b) their increased variety and (c) accelerated succession.

6. There is the closest connection between the distribution of organisms and the position of the layers of definite water masses in the system of vertical marine zones. In the Bay of Possjet the low border of the particular vertical zone lies at a depth of $5 \mathrm{~m}(0$ to $5 \mathrm{~m})$; its location is determined by the position of the upper layer of the surface Japanese marine water mass.

7. When carrying out biogeographical studies, in addition to comparing similar vertical zones, one should consider bionomically similar areas.

\section{LITERATURE CITED}

Drach, P., 1958. Perspectives in the study of benthic fauna of the continental shelf. In: Perspectives in marine biology. Ed. by A. A. Buzzati-Traverso. Univ. of Calif. pr., Berkeley, 33-46.

Forster, G. R., 1959. The ecology of Ecbinus esculentus. 1. Quantitative distribution and rate feeding. J. mar. biol. Ass. U. K., 38, 361-367.

Golikov, A. N., 1966. Ecological peculiarities of coastal marine bottom bicoenoses of Southern Primorye and Southern Sakhalin in connection with hydrological regime. Int. oceanogr. Congr. 2, 136-137 (Abstr.)

- \& Scarlato, O. A., 1965. Hydrobiological explorations in the Possjet Bay with diving equipment. [Russ.] In: Fauna morej Severo-Zapadnoj časti tichogo okeana (Fauna of the seas of the North-West Pacific). Akad. Nauk SSSR, Zool. Inst., Leningrad. (Issledovanija fauny morej [Explorations of the fauna of the seas] $3<11,5-21$.)

Hutchins, L. W., 1947. The bases for temperature zonation in geographical distribution. Ecol. Monogr. 17, 325-335.

Scarlato, O. A., Golikov, A. N. \& Grusov, E. N., 1964. Diving technique of hydrobiological investigations. [Russ.] Okeanologija 4, 707-719.

\section{Discussion (by correspondence) following the paper by Golikov \& SCARLato}

KINNE: Your interesting paper is in part devoted to the distribution of bottom biocoenoses. How did you distinguish neighbouring biocoenoses and how did you determine their borderlines? 
Golikov \& Scarlato: We distinguished biocoenoses as a rule by two or more species strongly dominating over others in their biomass. When carrying out direct observations under water with diving equipment an experienced hydrobiologist can easily visually trace the biocoenoses to be studied and their approximate limits. The detailing of the borders between biocoenoses and the separation of typical forms was undertaken after an analysis of quantitative collections was made by investigators within the limits of each biotope. The replacement of one dominant form by another serves as a good indicator of quantitative - qualitative changes in the life of the sea bottom and of the nature of the ecosystem, defining the borders between biocoenoses. In temperate waters, on the parts of the sea bottom we studied, a zonal or nearly zonal spread of life takes place. That is why the immediate recognition of biocoenoses is relatively simple, and the borders between them, even within the limits of one and the same ground, rather sharp.

KINNE: According to your results biocoenoses of shallow waters and half-closed coastal areas "are less resistant" than those existing off the open coast and at greater water depths. What exactly do you mean by "resistant" and how did you measure the degree of resistance?

Golikov \& SCarlato: We think the resistance or stability of biocoenoses to be their relative constancy or the time of their being in a state close to climax. Relatively less constancy and correspondingly quicker successions of biocoenoses in shallow waters and half-closed bays may be connected with a greater influence of climatic changes upon their components. In protected half-closed bays the rate of changes of biocoenoses may be considerably influenced also by progressively developing silting with all its ensuing consequences. We determined the degree of resistance of biocoenoses on the relative time of their existence in an invariable state. This was possible due to a study, lasting four years, of their condition during different seasons of the year, and due to a comparison of obtained data with literary data on the composition and distribution of the fauna and flora of this bay in the twenties and thirties of the twentieth century. 